\title{
CRIMINALIZATION OF ANIMAL CRUELTY IN CONTEXT: AN ALBANIAN PERSPECTIVE
}

\author{
Assist. Nita Shala, Ph.D.* \\ Assist. Prof. Avni Puka, Ph.D.** \\ Dr. Gianluigi Pratola***
}

UDK: $343.58(496.5)$

343.58:340.5

DOI: 10.3935/zpfz.71.6.05

Pregledni znanstveni rad

Primljeno: listopad 2021.

The Albanian legislature has been slow to comprehensively regulate and suitably penalize cruelty towards animals. During the second decade of building a democratic legal system, adopted legislation mandated administrative penalties for only a small number of acts of commission or omission that constituted cruelty to animals. A petition from 37,527 electors obliged the Committee of Laws at the Albanian Parliament to deliberate on the criminalization of animal cruelty for the first time in November of 2017. Two years later, on 18 July 2019, the Albanian Criminal Code was amended with six provisions criminalizing animal cruelty. How has context and other factors shaped the law in Albania with regards to animal cruelty? Authors aim to respond to this question through a functional method with a problem-solving contextual approach, engaging in an in-depth legal evaluation of

* Nita Shala, Ph.D. (IHEID); MSc (Oxon), Assistant, Faculty of Law, University of Prishtina, Rr. "Agim Ramadani”, 10000 Prishtinë, Kosovo; nita.shala@uni-pr.edu; ORCID ID: orcid.org/0000-0003-1518-0756

** Avni Puka, Ph.D., Assistant Professor, Faculty of Law, University of Prishtina, Rr. “Agim Ramadani”, 10000 Prishtinë, Kosovo; avni.puka@uni-pr.edu (Corresponding Author);

ORCID ID: orcid.org/0000-0002-7562-5078

*** Dr. Gianluigi Pratola, Prosecutor, Deputy Attorney General at the Italian Court of Cassation; International Expert for the EURALIUS Project in Albania, Ministry of Justice, Zogu I Bulevard, 1000 Tiranë, Albania; pratola@euralius.eu;

ORCID ID: orcid.org/0000-0003-1854-6055 
the Albanian legislation and comparative analysis on the topic. This work draws on deliberations from eight meetings of the Committee of Laws and consultation with nineteen Members of the Parliament, civil servants in responsible institutions, and representatives from civil society, to clarify how society's effort shaped the criminalization of cruelty towards animals in Albania. The discussion proceeds with a comparative legal analysis between proposed legislation and adopted changes in the Criminal Code with legislation in certain EU Member States and EU acquis. Concerns linger about whether criminalizing a behavior such as animal cruelty is the appropriate way to reduce the occurrence of this offence.

Keywords: animal cruelty, Criminal Code, Albania, comparative analysis

\section{INTRODUCTION****}

Animal cruelty as a social and legal problem gained recognition in Albania only in early 2000s, during the second decade of the country's transition into democracy, falling behind to Western culture which has had laws in place as far back as the 1800s regulating and criminalizing animal neglect, abuse, and fighting. ${ }^{1}$ Before these recent amendments, criminal provisions were not applicable even for cruelty towards wildlife or species in risk of extinction. Lex specialis regulating the veterinary services, hunting conditions, and protection of wildlife deemed animal cruelty as transgression condemnable by administrative penalties, most often in the form of monetary compensation. Sociological research outlays diverse reasons why cruelty against animals has been overlooked. ${ }^{2}$ One reason is society's general perception that violence towards animals is less significant compared to violence against humans. There is also the perception that crimes against animals are individual incidents. Also, since animals are voiceless victims, there is a low reporting rate of incidences. ${ }^{3}$

***** Authors would like to thank Ms. Katie Dunn for her valuable comments.

1 Favre, D.; Tsang, V., The development of the anti-cruelty laws during the 1800's, Detroit College of Law Review, vol. 1, no. 1, 1993, pp. 1-35; Priest, C., Enforcing Sympathy: Animal Cruelty Doctrine after the Civil War, Law \& Social Inquiry, vol. 44, no. 1, 2019, pp. 136-139; See also, Luke C.; Arluke, A., Physical cruelty toward animals in Massachusetts, 1975-1996, Society \& Animals, vol. 5, 1997, pp. 195-204; Anderson, J. L., The Origins and Efficacy of Private Enforcement of Animal Cruelty Law in Britain, Drake Journal of Agricultural Law, vol. 17, no. 2, 2012, pp. 263-310.

2 Piazza, J.; Landy, J. F.; Goodwin, G. P., Cruel nature: Harmfulness as an important, overlooked dimension in judgments of moral standing, Cognition, vol. 131, no. 1, 2014, pp. 108-124.

3 Mogbo, T. C; Oduah, F. N.; Okeke, J.; Ufele, A. N.; Nwankwo, O. D., Animal Cruelty: A Review, Journal of Natural Sciences Research, vol. 3, no. 8, 2013, pp. 94-98. 
In the Albanian public, animal cruelty has entered into the limelight after the publication of the "bears scandal". ${ }^{4}$ Fifty bears that were used to entertain people for profit were kept for prolonged periods of time in very small cages, preventing them from standing or sitting up right, and often, even from turning around. ${ }^{5}$ The scandal resonated with the Albanian public, leading to the set-up of the informal group "The Coalition to Save Albanian Bears". Consequently, Albania's Minister of Environment formed agreements with foreign government authorities to move these bears to institutions that had the knowledge and resources to care for the animals. ${ }^{6}$ More importantly, the scandal resulted in an initiative to criminalize animal cruelty. 37,527 Albanian citizens signed a proposal to amend the Criminal Code with animal cruelty offences and presented it to the Albanian Parliament on 6 November 2017. ${ }^{7}$ That marked the first time in the country's history, after nearly 30 years of being a democratic country, that electors used their Constitutional right of initiative to propose legislation.

The proposed amendments pushed the animal cruelty discourse into the legislative process. Yet, the proposal draft-Criminal Code had shortcomings. The proposal did not define "animals" in the applicable provisions. It did not delineate whether provisions applied to companion animals, domestic animals, or animals that people use for food, clothing, sports or entertainment. The definition of "animal cruelty" was missing and the elements comprising the criminal offence were unclear. Consequently, the proposal included disproportionate sanctions for vaguely defined criminal offences in the form of imprisonment, with some of the sanctions being unduly lenient, while others unduly harsh. Furthermore, these amendments risked infringing the principle of "legal security" by providing for the same actions both administrative condemnation and criminal punishment. They foresaw criminal liability for many conducts which were already regulated by special laws, namely the Law on Veterinary Services,

4 Dungler, H., Four Paws Foundation for Animal Welfare Annual Report, VIER PFOTEN International, 2016.

5 Wright, S., Shocking new pictures reveal the sickening cruelty suffered by brown bears in Albania, Daily Mail (22 August 2020); Wright, S., RESCUED: Lonely bear which became depressed and bit itself after being kept in a tiny cage by an Albanian restaurant will be moved to an animal sanctuary, Daily Mail (22 July 2020); Mejdini, F., Albania seeks to raise funds for bear shelter following the ill-treatment scandal, Reporter.al (24 June 2020).

6 Mejdini, F., Albania's caged bears enjoy freer life in Kosovo, Reporter.al (24 June 2020).

7 The deliberation on criminalization of animal cruelty in the Albanian Parliament began as an initiative of 20,000 electors which used their Constitutional right provided under Art. 81, point 1 to propose laws. Ligji nr. 8471, datë 22.11.1998 Kushtetuta e Republikës së Shqipërisë [Law nr. 8471 Constitution of the Republic of Albania], Fletorja Zyrtare [Official Gazette], no. 219/1998. 
Law on Hunting, Law on Protection of Wildlife, for which these laws mandated administrative condemnation. ${ }^{8}$

It took nearly two years of deliberation until these animal cruelty amendments to the Criminal Code were voted on in the Albanian Parliament. On 18 July 2019, the Parliament passed them. In their final form, these amendments included six provisions which codified criminal liability for the killing, abandonment, and cruel treatment of animals; the participation in, or organization of, fights between animals; and the utilization or harm of wild animals or those in risk of extinction. ${ }^{9}$

\section{METHODOLOGY}

In this Article, we deliberate on the first popular proposal to legislate animal cruelty under criminal law, and on the promulgated criminalization of cruelty towards animals in Albania. Two of the authors have served as external legal experts consulting the Committee of Laws on the deliberation of these legal amendments. To lead to a more coherent and consistent categorization of these offences and prescribed sentences, we engage in an in-depth domestic law analysis. Recognizing how comparative research has become almost compulsory in doctrinal legal research ${ }^{10}$, we engage in a functional method of comparative analysis on how animal abuse is regulated in nine jurisdictions, namely Austria, Croatia, Bulgaria, Italy, France, Germany, Greece, Slovenia and the Netherlands. These practices reflect diverse routes to address similar challenges, and offer models for emulation in the Albanian context. ${ }^{11}$ As Albania has confirmed its European perspective, and is currently at the stage of having been awarded

8 Ligj nr. 10253, datë 11.3.2010 Për gjuetinë [Law on Hunting], Fletorja Zyrtare [Official Gazette], no. 39/2010; Ligj nr. 10465, datë 29.9.2011 Për shërbimin veterinar në Republikën e Shqipërisë [Law on Veterinary Services], Fletorja Zyrtare [Official Gazette], nr. 143/2011; Ligj nr. 10 006, datë 23.10.2008 Për mbrojtjen e faunës së egër [Law on Protection of Wildlife], Fletorja Zyrtare [Official Gazette], nr. 153/2008.

9 Ligj nr. 44/2019, date 18.7.2019 Për disa shtesa dhe ndryshime në Ligjin nr. 7895, date 27.1.1995 "Kodi Penal i Republikës së Shqipërisë [Law amending the Criminal Code of the Republic of Albania], Fletorja Zyrtare [Official Gazette], nr. 131/2019.

10 Van Hoecke, M., Methodology of Comparative Legal Research, Law and Method. vol. 1, 2014, pp. 1-35.

11 See, Schmitthoff, M., The Science of Comparative Law, Cambridge Law Journal, vol. 7, no. 1, 1939, p. 96 . 
candidacy status by the $\mathrm{EU}^{12}$, it has to achieve a necessary degree of compliance with the EU acquis. Consequently, we analyze the applicable EU law with regards to the topic.

Individual interviews allowed us to better understand perspectives of different stakeholders: representative members of the Parliament, the government, and civil society, as to which conducts shall be deemed an offence and the suitable punishment. Eight meetings of the Law Committee were held between November 2018 and March 2019. During the same period, nineteen structured interviews were conducted in three focus group meetings with eight interviews with MPs and a member of the government, four interviews with civil servants in institutions dealing with animal cruelty, and six interviews with representatives from six different civil society organizations (Table 1). Findings and conclusions are detailed and summarized in the following sections.

\section{Table 1. Groups and dates}

\begin{tabular}{|l|l|c|}
\hline \multicolumn{1}{|c|}{ Focus groups } & \multicolumn{1}{c|}{ Stakeholder } & Date of meeting \\
\hline Group A (9 persons) & $\begin{array}{l}\text { Members of Parliament and } \\
\text { Representatives of Government }\end{array}$ & $13 / 12 / 2018$ \\
\hline Group B (4 persons) & Civil servants & $14 / 01 / 2019$ \\
\hline Group C (6 persons) & Civil society & $20 / 01 / 2019$ \\
\hline
\end{tabular}

\section{ON THE PROPOSAL TO CRIMINALIZE ANIMAL CRUELTY AND SUGGESTED PUNISHMENTS}

Several reports in Albania suggest that many animals suffer from abuse and that the incident rate of animal cruelty for commercial benefit, particularly regarding wild species, is significant. ${ }^{13}$ Since 2015, the international animal welfare organization, 'Four Paws', has reported that 30 bears have been saved after being kept in tiny cages next to restaurants and hotels throughout the country. ${ }^{14}$ In 2018, international press reported that 11 wild animals were kept

12 Albania submitted the formal application for EU Membership in 2009; in June 2014, Albania was awarded candidate status by the EU. In March 2020, members of the European Council endorsed the General Affairs Council's decision to open accession negotiations with Albania. See, European Commission, Albania 2020 Report, SWD(2020) 354 (6 October 2020).

13 See, op. cit. (fn. 5 and 6).

14 FOUR PAWS, Bears in Albania: The cruel keeping of bears in captivity nearly set to end, 2021 (7 October 2021). In 2016, same organization reported having saved eighteen bears, see Reported to the interviewer in op. cit. (fn. 5). 
in captivity in a private zoo, including three lions and one bear. ${ }^{15}$ Even more concerning is the reported decline of the Albanian wild animals due to illegal hunting. For example, only half of the 200 pairs of eagles counted in 1990s can now be found. ${ }^{16}$ Organizations have reported a surge of as much as 10 times the number of people engaging in illegal hunting in 2020 and 2021, seemingly due to the Covid-19 pandemic. ${ }^{17}$ These findings indicate that, among others, the applicable legal framework prescribing administrative condemnation may have not been enough to prevent offenders from engaging in such violence.

The Albanian Parliament acted upon the proposed draft-law submitted to the Committee of Laws by 37,527 citizens, requesting criminalization of animal cruelty. The proposal encompassed six articles that criminalized killing animals, maltreating animals, organizing or participating in animal fights, illegal experimenting on animals, using the skin of companion animals or wildlife, and killing or keeping in captivity an animal at risk of extinction. ${ }^{18}$ For these offences, the proposal mandated punishment by prison from four months to two years. The necessity to criminalize animal cruelty was shared among all interviewed stakeholders; and they agreed on the preventive function of criminalization of the killing, forms of maltreatment, and the use of animals for profit. As such, all stakeholders welcomed, in principle, the request to criminalize these transgressions. Yet, the proposed amendments were characterized by challenges. As such, in the following sections, while clarifying on the content of the proposed amendments, authors clustered the analysis into three identified challenges related to this proposal: (i) terminological and normative unclarity; (ii) disproportional punishment; (iii) legal uncertainty as to the offence being a criminal offence and administrative misdemeanor.

\subsection{Terminological and normative unclarity}

With the intention to expand the legal protection of animals, the citizens' proposal suggests criminalization of acts causing harm or death to animals.

15 Agerholm, H., "Rundown prison": Three lions and one bear among animals rescued from "shocking” Albanian zoo, The Independent, 2018 (30 December 2021).

16 FOUR PAWS, Illegal wildlife trade in Albania is out of control, 2020 (29 December 2021).

17 Emiri, G., Illegal hunting set new records during the pandemic. Reporter.al, 2021 (30 December 2021).

18 See, Nismë e qytetarëve për miratimin e disa dispozitave në Kodin Penal kundër dhunës $n d a j$ kafshëve [Citizens proposal to ammend the Criminal Code with provisions on violence against animals], Proposal submitted to the Albanian Parliament, https:// www.parlament.al/Files/ProjektLigje/nisma-e-qytetareve.pdf (15 February 2021). 
However, the terminology "animal" and expressions used, such as "wounding," "subduing to actions which bring suffering," "illegal experiments," "inappropriate hygienic or sanitary conditions,", and "unsuitable services" are indeterminate, imprecise, vague, and consequently ambiguous expressions. There is unclarity in terms of content and applicability of these provisions.

The general term of "animal" is a special form of indeterminacy, as it obscures what is embodied in these legal provisions. It is unclear what species are implicated, and most importantly, it opens up the laws' application to all types of animals. The definition of animal, found in the Albanian Law on Veterinary Services, is general and may account as animal any living species. ${ }^{19}$ The same law differentiates between farm animals, animals used in experiments, exotic animals, animals for slaughter and companion animals. ${ }^{20}$ The proposed amendments failed to specify the type of animal to which the acts of killing and maltreatment are applicable. The possible confusion about the pertinent species could have been avoided had the definition of the "animal" been clarified in other applicable law, as in the case of Croatia's special law on animals; ${ }^{21}$ or, had the proposal been limited in application to a special group of animals, such as vertebrates ${ }^{22}$, animals belonging to another person ${ }^{23}$, or wild species or those

19 Art. 4, para. 26, Law on Veterinary Services, op. cit. (fn. 8), which reads:

Animal means ungulate (horses, donkeys, mules), bi-ungulate (cattle, buffaloes, sheep, goats and pigs), poultry (chickens, ducks, gooses, turkeys, ostrich and pigeons), dogs, cats, rabbits, pet animals, bees, silkworm, fish, crustaceans, molluscs, frogs, snakes, wild and farmed game animals, experimental animals and other species.

Art. 4, paras. 27-33, Ibid.

21 Zakon o zaštiti životinja [Animal Protection Act of the Republic of Croatia], Narodne novine [Official Gazette], no. 102/2017. Consulted in English language at: http:// www.mvep.hr/files/file/dokumenti/prevodenje/zakoni/25-Zakon-o-za\%C5\%Al titi-\%C5\%BEivotinja--NN-102-17-ENG.pdf (13 February 2020).

See Art. 222, para. 1, Strafgesetzbuch - StGB [Austrian Criminal Code], Amstblatt [Official Gazette], nr. 60/1974 (last amended 5.2.2020), which reads: "Ebenso ist zu bestrafen, wer ein Wirbeltier mutwillig tötet", translated to English: "in the same way shall be punished whoever kills a vertebrate out of a mood".

23 Art. 350, para. 2, Wetboek van Strafrecht [Criminal Code of Kingdom of Netherlands], Staatsblad [Official Gazette], accessed the official translated version at: http://www.ejtn.eu/PageFiles/6533/2014\%20seminars/Omsenie/WetboekvanStrafrecht_ENG_PV.pdf (13 February 2021), which reads:

"Any person who intentionally and unlawfully kills [...] an animal belonging in whole or in part to another". 
in risk of extinction. ${ }^{24} \mathrm{~A}$ narrow definition of animals would have contributed to a more certain citizens' proposal.

In addition to the definition of animals, provisions proposed by the citizens listed a series of acts deemed to constitute animal "maltreatment": the abandoning of domestic animals or those kept in captivity; wounding of an animal or subduing it to actions which bring suffering to the animal, without a legal reason; obliging an animal to provide services, work or undertake actions which go beyond ethological characteristics of the animal, motivated by malice or without reason; undertaking acts which contradict the wellbeing or the keeping of animals in inappropriate hygienic or sanitary conditions; and acts of torture, poisoning or any other action that results in deformity or permanent health damage of the animal or loss of life. While the meaning of most of these conducts is clarified by other applicable legislation (for example, the captivity of animals being that of holding animals to prevent their escape $)^{25}$, others, such as, "wounding" and "subduing action" as well as the qualification "without a legal reason" are unclear and lack qualification with elements, risking the expansion of application of these provisions into nearly any action against any living species. Under this language, a farmer using typical methods to manage and kill animals would be subject to the criminal offence. Under this vague definition of animal maltreatment, stepping on an ant, killing a fly, or any number of actions towards any type of animal could be a criminal offence. Given that the proposal aimed to criminalize these acts, it was critical to better define the elements of these offences.

The proposal also aimed to criminalize experiments on animals conducted in violation of rules, regulations, and protocols. ${ }^{26}$ The terminology "illegal" experiments used in the proposal made it unclear whether this formulation referred to experiments undertaken contrary to stipulated conditions by special law, or whether the scope of application is even larger. For a similar criminal offence, French law provides clarity by defining the applicable acts as experiments or experimental scientific research on animals carried out "without complying with the provisions laid down by Decree of the Conseil d'Etat". ${ }^{27}$ This could be

24 See Art. 200, para. 1, Kazneni Zakon [Croatian Criminal Code], Narodne Novine [Official Gazette], no. 144/2012.

25 See Law on Veterinary Services, op. cit. (fn. 8).

26 Art. 5 Citizens proposal to amend the Criminal Code, op. cit. (fn. 18).

27 Art. 521.2, Code pénal de la République française [Penal Code of the Republic of France], Official Gazzete [Journal officiel], no. 286/2009. 
emulated in Albania by referencing the Albanian Law on Veterinary Service, which regulates scientifically experimenting with animals. ${ }^{28}$

\subsection{Disproportional Punishment}

In addition to the problem of vaguely defined violations, the citizens' proposal included disproportionate sanctions. ${ }^{29}$ The proposal suggested a punishment by a minimum of six months and up to two years of imprisonment for the act of killing an animal; ${ }^{30}$ a punishment of three years' imprisonment for conducting experiments on animals without following the legally provided protocols; ${ }^{31}$ one to two years of imprisonment for anyone promoting, organizing, or leading of fights between animals; anyone that holds, grows, trains or gives animals for fights; ${ }^{32}$ three to six months of imprisonment for anyone producing and distributing images of fights between animals; ${ }^{33}$ imprisonment from one to three years for anyone who uses the skin of wildlife or animals in risk of extinction; and a punishment by imprisonment from two to three years in cases of killing or keeping in captivity of wildlife animals in risk of extinction, with intention to profit. ${ }^{34}$

The mandatory minimum sentence of six months of imprisonment for the act of killing an animal is harsher than in any of the nine studied legislations. Seven EU Member states: Italy, Croatia, Slovenia, France, Germany, Austria and the Netherlands do impose prison sentences for certain instances of killing an animal. However, the prison sentences are much shorter than the six-month minimum described in the Albanian citizens' petition. In Italy there is a mandatory minimum sentence of three months of imprisonment ${ }^{35}$, but in all other jurisdictions studied in this review, there were no mandatory minimum

Art. 76, Law on Veterinary Services, op. cit. (fn. 8).

Arts. 1-6, Citizens proposal to amend the Criminal Code, op. cit. (fn. 18).

Art. 1, Ibid.

Art. 3, Ibid.

Art. 4, Ibid.

Art. 5, Ibid.

Art. 6, Ibid.

35 Art. 544-bis, para. .1, Codice Penale [Italian Criminal Code], Gazzetta Ufficiale [Official Gazette], nr. 36/2019. 
sentences, but rather mandatory maximum prison sentences, varying from up to one $^{36}$, two ${ }^{37}$ or three ${ }^{38}$ years of imprisonment.

Other EU countries also separate the offences of maltreatment and cruelty, imposing only administrative fines for maltreatment. ${ }^{39}$ For cruelty offences, EU countries increase the punishment, but still not to the level called for in the Albanian proposal. The proposed Albanian punishment for acts of cruelty was three times harsher than what has been embraced in the criminal codes of the EU countries. Criminal law in continental Europe seems to consider the criminalization of citizens' behavior as the "ultima ratio" of legislation, and in most EU jurisdictions, severe violations or even killing of an animal is punishable by an administrative penalty. ${ }^{40}$

The Albanian proposal was also harsher than the EU member states in punishments for harm caused to wildlife and species in risk of extinction. The citizens' proposal called for a minimum prison sentence while EU member states have mandatory maximum prison sentences not exceeding three years ${ }^{41}$, or up to five years. ${ }^{42}$ For example, in 2004, the Italian legislature established the offence of using the skin or fur of protected animals for commercial gain, with the punishment of imprisonment from three months to one year, or a fine. ${ }^{43}$ The corresponding provisions in the Albanian citizens' proposal have the punishment listed as a minimum of one year in prison.

36 Art. 34l, para. 2, Kazenski Zakonik [Slovenian Criminal Code], Uradni List [Official Gazette], no. 55/2002; Art. 205, para. 1, Croatian Criminal Code, op. cit. (fn. 24).

37 Art. 222, paras. 1 and 2, Austrian Criminal Code, op. cit. (fn. 22).

38 Art. 350, Criminal Code of Kingdom of Netherlands, op. cit. (fn. 23).

39 See, for example, Animal Protection Act of Croatia, op. cit. (fn. 21); Wet Dieren [Animal Protection Act of the Kingdom of Netherlands], Staatsblad [Official Gazette], no.05/11.

40 See for example, the case of Greece in which the administrative fine for killing an

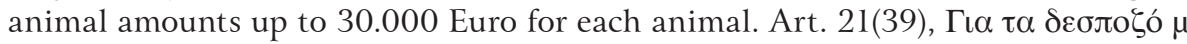

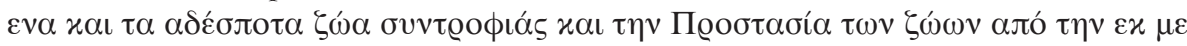

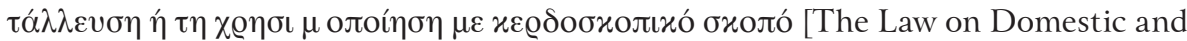

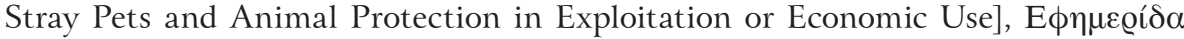

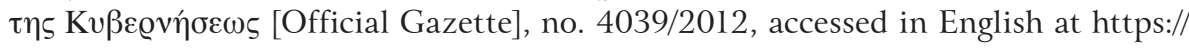
www.digihome.eu/law-number-40392012-government-gazette-a-15-for-home-petsand-stray-pets-and-to-protect-animals-from-exploitation-or-use-for-profit/ (23 December 2021).

41 Art. 200, para. 1, Croatian Criminal Code, op. cit. (fn. 24).

42 Art. 344, Slovenian Criminal Code, op. cit. (fn. 36).

43 Art. 727, para. 2, Italian Criminal Code, op. cit. (fn. 35). 
The proposed penalties risk infringing the principle of proportionality, a fundamental requirement in criminal justice systems. ${ }^{44}$ These proposals, especially in relation to killing and maltreatment of (all) animals do not seem appropriate and necessary to attain the preventive and rehabilitative aims, and the disadvantages caused are disproportionate to the aim pursued ${ }^{45}$ It is questionable if these harsh sentences are necessary to deter persons from treating animals inappropriately. Less severe sanctions could be sufficient in order to achieve the same objective. Furthermore, these provisions would contradict decriminalization, an objective of the massive justice reform undertaken in Albania since 2016 which involves revisiting of a large number of qualified offences under the Criminal Code in order to soften the punishments and make sentences proportionate to the offence. ${ }^{46}$

\subsection{Legal uncertainty as to the offence being a criminal offence and administrative misdemeanor}

Diverse acts that instill suffering on an animal without a legal reason are liable for administrative misdemeanor under Albanian law. ${ }^{47}$ The causing of torture, physical or verbal violence, inhumane treatment or any other action that brings suffering to the animal of the proposed paragraph 2 is qualified in the Law on Veterinary Services as administrative contravention punished by a fine. ${ }^{48}$ The same law qualifies as administrative contravention punished by a fine making an animal provide services, work or undertake actions which go beyond ethological characteristics of the animal, motivated by evil or without reason. ${ }^{49}$ Animal fighting or use of animals for performance leading to pain, injury or death are likewise punishable as an administrative misdemeanor. ${ }^{50}$

44 See, Art. 7, European Convention of Human Rights, https://www.echr.coe.int/documents/convention_eng.pdf (10 December 2020), Art. 49(3), EU Charter of the Fundamental Rights of the European Union, https://eur-lex.europa.eu/legal-content/ EN/TXT/?uri=CELEX:12012P/TXT (10 December 2020). See also, Articles 17, 116 and 122, Constitution of the Republic of Albania, op. cit. (fn. 7).

45 A standard set by the European Court of Justice in the ECJ, Case C-356/97, Molkereigenossenschaft Widergeltingen eG v Hauptzollmant Linau, (2000), ECR I 5461.

Objective Nr. 5, Criminal Justice of the Strategy of the Judicial Reform in Albania, 24 July 2015 https://rm.coe.int/strategy-on-justice-system-reform-24-07-2015en/16809eb53b (10 September 2020).

47 See Law on Veterinary Services, op. cit. (fn. 8); Law on Hunting, op. cit. (fn. 8).

48 Arts. 76 and 134, Law on Veterinary Services, op. cit. (fn. 8).

49 Art. 76, para. (ç), Ibid.

50 Art. 76, para. (b), Ibid. 
The Law on Administrative Misdemeanors regulates administrative misdemeanors as actions or omissions that cause a harm or potential harm to the society, however the possible danger posed for the society is deemed lower compared to that from a criminal offence. ${ }^{51}$ Doctrine has been critical of situations in which the same action is punishable under special law(s) as an administrative misdemeanor and at the same time as a criminal offence under the Criminal Code. $^{52}$ This legal chaos was attempted to be resolved by a unifying decision of the Albanian Constitutional Court aimed to ensure "reliability of State legislation and stability of the law for the regulated relations" by confirming the precedence of the application of the Criminal Code and at the same time requesting a clear demarcation of criminal acts and administrative offences. ${ }^{53}$ Thus, the citizen's proposal risked infringing the Constitutional Court's decision and the guiding principle of "legal security", through creating a contradiction in the applicable law in Albania, by providing for the same actions both administrative condemnation and criminal punishment.

\section{DISCUSSION ON CRIMINALIZATION OF ANIMAL CRUELTY IN ALBANIA, IN LIGHT OF COMPARATIVE LEGAL ANALYSIS AND INTERVIEWS WITH STAKEHOLDERS}

New provisions criminalizing harm caused to animals were adopted on 18 July 2019 and entered into force on 18 September 2019. ${ }^{54}$ Enacted amendments to the Criminal Code covered: (i) killing, (ii) maltreatment and (iii) abandonment of animals; (iv) participation in and organization of fights between animals; and (v) harming wild animals or species in risk of extinction. In the following section, we provide an account of the elements of these offences and foreseen punishments, and how these provisions stand in comparison to the practices in the identified European jurisdictions and the EU acquis.

51 Ligji nr. 10 279, datë 20.5.2010 Për Kundërvajtet Administrative [Law on Administrative Misdemeanors], Fletorja Zyrtare [Official Gazette], nr. 120/2010. For a perspective on doctrine see, Cani, E., Legal Regulation of Administrative Misdemeanours: European Principles and the Case of Albania, International Journal of Innovation Sciences and Research, vol. 4, no, 3, 2015, pp. 105-112.

52 Çomo, J., E Drejta Administrative e RSH [Administrative Law in the Republic of Albania], Book 3, 2016.

53 Decision of the Constitutional Court nr. 26, dated 02.11.2005, Summary of Decisions, 2005, pp. 223.

54 Albanian Criminal Code, op. cit. (fn. 8). 


\subsection{Killing an animal}

Intentionally causing the death of a companion animal creates a criminal offence, punishable with a fine or imprisonment of up to six months. ${ }^{55}$ The adopted provision differed from the initial proposal in terms of scope of application and punishment. It is only the killing of companion animals that is deemed illegal, not simply any type of animal. Under Albanian legislation, companion animals are species that are kept and raised by humans at home and not for profit; ${ }^{56}$ and, as clarified by an Order from the Albanian Ministry of Agriculture, Food and Consumer Protection, include pets, livestock, and beasts of burden. ${ }^{57}$

Also, the offender can be sentenced by a fine or a maximum period of six months of imprisonment, rather than two years.

The intentional killing of an animal is criminalized in the EU Member States that are the subject of analysis in this part of work, namely Croatia, Italy, Slovenia, Austria and the Netherlands. However, they are different in how they qualify the elements comprising the offence. The Austrian legislature criminalized the "intentional killing of a vertebrate." 58 The Slovenian legislature has criminalized "cruel death caused to a tortured animal". 59 The Dutch legislature criminalized killing an animal under the custody or control of another person. ${ }^{60}$ The killing of an animal without a justified reason is also a criminal offence under the Croatian Criminal Code. ${ }^{61}$ The Italian legislature codified "the causing of death of an animal, for cruelty and unnecessarily." This Italian version was also reflected in the proposal from the Albanian electorate. ${ }^{62}$

With regards to sentencing, the Italian legislature set the punishment as imprisonment from a minimum of three months to a maximum of 18 mon-

55 Art. 207/b, Albanian Criminal Code, op. cit. (fn. 8).

56 Art. 4, para. 33 Law on Veterinary Services op. cit. (fn. 8).

57 Order no. 5369, dated 18.12.2012 from the Ministry of Agriculture, Food and Consumer Protection lists the types of companion animals, categorizing them into these main groups: pets (dogs, cats); "smelly animals" in albanian "qelbes"; invertebraters, poultry and mamals (page nr 6), https://bujqesia.gov.al/wp-content/uploads/2017/12/Kerkesat_e_Shendetit_te_Kafsheve.pdf (30 December 2021).

Art. 222, para. 3, Austrian Criminal Code, op. cit. (fn. 22).

59 Art. 341, Slovenian Criminal Code, op. cit. (fn. 36).

60 Art. 350, Criminal Code of Kingdom of Netherlands, op. cit. (fn. 23).

61 Art. 205, para. 1, Croatian Criminal Code, op. cit. (fn. 24).

62 Art. 544-bis, para. 1, Italian Criminal Code, op. cit. (fn. 35). 
ths. ${ }^{63}$ Slovenian, Austrian and the Netherlands' Criminal Codes set only the upper limit of a sentence, namely a maximum period of imprisonment of one year; ${ }^{64}$ two years; ${ }^{65}$ three years. ${ }^{66}$ The following table depicts qualifications of elements of criminal offence in the proposed draft, adopted version in the Albanian, Italian, Austrian, Dutch, Croatian and Slovenian Criminal Codes and respective sentences.

Table 2. Elements of animal killing offences and corresponding sentences in Albanian, Italian, Austrian, Dutch, Croatian and Slovenian Criminal Codes.

\begin{tabular}{|c|c|c|c|c|c|c|c|}
\hline PROVISION & $\begin{array}{l}\text { Albania- } \\
\text { Proposal }\end{array}$ & $\begin{array}{l}\text { Albania- } \\
\text { Adopted }\end{array}$ & Italy & Austria & $\begin{array}{l}\text { Nether- } \\
\text { lands }\end{array}$ & Croatia & $\begin{array}{c}\text { Slove- } \\
\text { nia }\end{array}$ \\
\hline $\begin{array}{l}\text { Killing an animal } \\
\text { for cruelty or } \\
\text { unnecessarily }\end{array}$ & $\begin{array}{c}6 \text { months- } \\
2 \text { years }\end{array}$ & - & $\begin{array}{c}\text { 3-18 } \\
\text { months }\end{array}$ & - & - & - & - \\
\hline $\begin{array}{l}\text { Killing an animal } \\
\text { without a justified } \\
\text { reason }\end{array}$ & - & - & - & - & - & $\begin{array}{l}\text { - up to } \\
\text { l year }\end{array}$ & - \\
\hline $\begin{array}{l}\text { Killing, } \\
\text { a vertebrate out of } \\
\text { mood }\end{array}$ & - & - & - & $\begin{array}{l}- \text { up to } \\
2 \text { years }\end{array}$ & - & - & - \\
\hline $\begin{array}{l}\text { Intentionally and } \\
\text { unlawfully killing } \\
\text { an animal, } \\
\text { which belongs to } \\
\text { another person }\end{array}$ & - & - & - & - & $\begin{array}{l}- \text { up to } \\
3 \text { years }\end{array}$ & - & - \\
\hline $\begin{array}{l}\text { Causing the death, } \\
\text { to a tortured animal }\end{array}$ & - & - & - & - & - & - & $\begin{array}{l}\text { - up to } \\
\text { l year }\end{array}$ \\
\hline $\begin{array}{l}\text { Killing an animal } \\
\text { using a firearm }\end{array}$ & 1-2 years & - & - & - & - & - & - \\
\hline $\begin{array}{l}\text { Intentional killing } \\
\text { of a companion } \\
\text { animal }\end{array}$ & - & $\begin{array}{l}\text { Fine or } \\
\text { up to } 6 \\
\text { months }\end{array}$ & - & - & - & - & - \\
\hline
\end{tabular}

63 Ibid.

${ }^{64}$ Art. 341, para. 2, Slovenian Criminal Code, op. cit. (fn. 36): Art. 205, para. 1, Croatian Criminal Code, op. cit. (fn. 24).

65 Art. 222, paras. 1 and 2, Austrian Criminal Code, op. cit. (fn. 22).

66 Art. 350, Criminal Code of Kingdom of Netherlands, op. cit. (fn. 23). 


\subsection{Abandonment of domestic animals and harm caused to third parties}

The Members of the Committee of Laws kept the General Public's proposal section about making it a criminal offence to abandon a companion animal without a reasonable cause or excuse, punishable with a fine or up to six months imprisonment. ${ }^{67}$ They did so because applicable legislation does not recognize such action as offence requiring administrative liability. Several European States' jurisdictions, such as Switzerland, Slovenia and Germany qualify abandonment of domestic animals as contravention sanctioned with administrative penalty. ${ }^{68}$ The Albanian legislature decided to emulate these practices, while also following the example of the Italian and Austrian legislatures that created a criminal liability for the offence. In the Italian Criminal Code, it is provided that whoever abandons a domesticated animal or animals that have acquired habits during a stay in captivity is deemed to have maltreated the animal and is punished by imprisonment of up to one year or fine. ${ }^{69}$ The Austrian Criminal Code defines the criminal offence as the release in freedom of an animal that is incapable of living in freedom, with a punishment of up to two years of imprisonment. ${ }^{70}$ As noted, under the Albanian Criminal Code, there is slightly more freedom when it comes to provided punishment, allowing the possibility to be punished by a fine or up to six months imprisonment.

Deliberations at the Committee of Laws brought to light a concern among the Albanian public of owners or holders of aggressive dogs which do not place muzzles on the animal. As such, the same provision provides also for criminal liability for non-placement of muzzles on companion animals when in public places or in open spaces for the public. The provision requires that harm be caused to the health of a person as constitutive element of this offence, and provides for three levels of liability. First, if due to the non-placement of the muzzle the animal causes "consequences to the detriment of the health of a person" the owner or holder of the animal is punished by fine or up to six months imprisonment. Second, if the animal seriously injures a person, the owner is punished by a minimum of one year of imprisonment and up to five years.

67 Art. 207/a, Albanian Criminal Code, op. cit. (fn. 8).

68 Art. 4, para. 2 of the 2005, Swiss Animal Welfare Act; paragraph 3, item 3 of the 1972 Animal Protection Act of Germany; Art. 15, para. 1, item 12 of the 1999 Animal Protection Act of Slovenia; Art. 5, para. 1 of the Animal Protection Act of Croatia, op. cit. (fn. 21).

69 Art. 727, Italian Criminal Code, op. cit. (fn. 35).

70 Art. 222, para. 1, Austrian Criminal Code, op. cit. (fn. 22). 
Third, if the animal causes the death of a person, the conduct is punishable by imprisonment from three years to up to ten years. ${ }^{71}$

\subsection{Maltreatment of animals}

The Albanian legislature has criminalized cruel maltreatment or cruel infliction of unnecessary suffering, punishable by a fine or up to three months in prison. ${ }^{72}$ In the studied EU Member States' legislation, there is variance in what behaviors are considered maltreatment or abuse of animals. The Italian legislature criminalized the subduing of an animal to acts of torture or unbearable work. ${ }^{73}$ Under the Austrian Criminal Code, animal cruelty consists of intentional rough mistreatment, or infliction of unnecessary pain, abandonment of domesticated animal unable to live in freedom as well as exposing an animal to an excruciating state of pain negligently. ${ }^{74}$ Similarly, the Criminal Code of Slovenia provides that anyone who is cruel to animals or causes them severe suffering is criminally responsible for maltreatment of an animal. ${ }^{75}$ Under the Croatian Criminal Code, the severe maltreatment, infliction of unnecessary pain, or putting the animal through unnecessary suffering stipulates criminal responsibility. Another form of maltreatment identified under the Croatian Criminal Code consists of negligent deprivation of an animal of food or water, or exposure of the animal to conditions of hardship over a long period of time. ${ }^{76}$ Under the French Criminal Code, it is defined as the "unnecessary infliction, in public or otherwise, of serious maltreatment, including sexual maltreatment, towards or the commission of an act of cruelty on any domestic or tame animal, or any animal held in captivity" ${ }^{77}$

With regards to punishment, the Albanian legislature provided for most lenient sanction. The French and Austrian legislature stipulated a punishment of up to two years of imprisonment. ${ }^{78}$ The Dutch and Slovenian legislatures created

\footnotetext{
71 Art. 207/a, Albanian Criminal Code, op. cit. (fn. 8).

72 Art. 207/c, Albanian Criminal Code, op. cit. (fn. 8).

73 Art. 544-ter, Italian Criminal Code, op. cit. (fn. 35).

74 Art. 222, para. 1, Austrian Criminal Code, op. cit. (fn. 22).

75 Art. 341, Slovenian Criminal Code, op. cit. (fn. 36).

76 Art. 205, paras. 1 and 3, Croatian Criminal Code, op. cit. (fn. 24).

77 Art. 521-1, Penal Code of the Republic of France, op. cit. (fn. 27).

78 Ibid.; Art. 222, para. 1, Austrian Criminal Code, op. cit. (fn. 22).
} 
a punishment with imprisonment of at most one year or six months or a fine. ${ }^{79}$ Under the Italian Criminal Code, the stipulated punishment is a minimum of three months' imprisonment up to one year. ${ }^{80}$ Table no. 3 below presents the elements of criminal offences in the proposed draft with regards to maltreatment of animals, the adopted version in the Albanian, Italian, Austrian, French, Dutch, Croatian and Slovenian Criminal Codes and the respective sentences.

Table 3. Elements of animal maltreatment offences and corresponding sentences in Albanian, Italian, Austrian, Dutch, Croatian and Slovenian Criminal Codes.

\begin{tabular}{|c|c|c|c|c|c|c|c|}
\hline PROVISION & $\begin{array}{l}\text { Albania- } \\
\text { Proposal }\end{array}$ & $\begin{array}{l}\text { Albania- } \\
\text { Adopted }\end{array}$ & Italy & $\begin{array}{c}\text { Austria } \\
\text { and } \\
\text { France }\end{array}$ & $\begin{array}{l}\text { Nether- } \\
\text { lands }\end{array}$ & Croatia & Slovenia \\
\hline $\begin{array}{l}\text { Maltreating } \\
\text { an animal } \\
\text { or inflicting } \\
\text { unnecessary } \\
\text { suffering } \\
\text { on it, } \\
\text { cruelly }\end{array}$ & - & $\begin{array}{l}\text { Fine or } \\
\text { up to } 3 \\
\text { months }\end{array}$ & - & $\begin{array}{c}\text { - up to } 2 \\
\text { years }\end{array}$ & $\begin{array}{l}\text { - at most } \\
1 \text { year }\end{array}$ & $\begin{array}{c}\text { - not } \\
\text { exceeding } \\
\text { l year }\end{array}$ & $\begin{array}{l}\text { Fine or } \\
\text { up to } 6 \\
\text { months }\end{array}$ \\
\hline $\begin{array}{l}\text { Wounding } \\
\text { an animal } \\
\text { or subduing } \\
\text { it to actions } \\
\text { which bring } \\
\text { suffering, } \\
\text { "without a } \\
\text { legal reason" }\end{array}$ & $\begin{array}{l}4 \text { months } \\
\text { - } 1 \text { year }\end{array}$ & - & - & - & - & - & - \\
\hline $\begin{array}{l}\text { Causing } \\
\text { suffering to } \\
\text { an animal, } \\
\text { for cruelty or } \\
\text { unnecessarily }\end{array}$ & - & - & $\begin{array}{l}3 \text { months } \\
-1 \text { year }\end{array}$ & - & - & - & - \\
\hline $\begin{array}{l}\text { Severely } \\
\text { maltreating } \\
\text { an animal, } \\
\text { causing its } \\
\text { death } \\
\end{array}$ & $\begin{array}{c}\text { 6-19 } \\
\text { months }\end{array}$ & - & - & - & - & - & $\begin{array}{l}\text { Fine or } \\
\text { up to } 1 \\
\text { year }\end{array}$ \\
\hline
\end{tabular}

79 Art. 254, Criminal Code of Kingdom of Netherlands, op. cit. (fn. 23); Art. 341, Slovenian Criminal Code, op. cit. (fn. 36).

80 Art. 544-ter, Italian Criminal Code, op. cit. (fn. 35). 


\subsection{Organizing or participating in fights between animals}

The Albanian Criminal Code codifies the fights between animals as follows:

"Promoting, organizing or directing fights between animals that cause the suffering or torture of animals is punishable by a fine or up to three months in prison. Giving animals for fights, raising or training animals for the purpose of use or sale for fights, is punishable by a fine or up to six months in prison. Placing bets on fights between animals is punishable by a fine or up to two months in prison. When the offence has resulted in the death of the animal, it is punishable by imprisonment of up to six months." ${ }^{11}$

In France, organizing cockfights is a crime punishable by up to two years of imprisonment. ${ }^{82}$ However, the French legislature specifically excludes application of this provision in different parts of the country where "an uninterrupted traditional practice [of bullfights or cockfights] can be established". ${ }^{33}$ Similarly, the Bulgarian legislature provided for punishment by prison for fights between animals, however only for organizing animal fights and providing animals for fights and if the (a) the deed is committed repeatedly; or (b) the deed is committed by a veterinary surgeon or technician, an official or an individual performing activity or profession related to breeding, care and treatment of animals. ${ }^{84}$ The Italian Criminal Code is very similar in defining the act and the punishment. ${ }^{85}$ In the following table are presented the composing elements of the criminal offences relating to animal fights and corresponding sanctions stipulated in the Albanian case and Italian Criminal Code.

Table 4. Elements of animal fighting offences and corresponding sentences in Albanian, and Italian Criminal Code.

\begin{tabular}{|l|l|l|l|}
\hline \multicolumn{1}{|c|}{ PROVISION } & \multicolumn{1}{c|}{ Albania- proposal } & \multicolumn{1}{c|}{ Albania- adopted } & \multicolumn{1}{c|}{ Italy } \\
\hline $\begin{array}{l}\text { Promoting, organizing } \\
\text { or directing matches }\end{array}$ & $\begin{array}{l}\text { 1-2 years and a fine 100.000 } \\
\text { to 300.000 Albanian Lekë }\end{array}$ & $\begin{array}{l}\text { Fine or imprisonment } \\
\text { up to 3 months }\end{array}$ & 1-3 years \\
\hline $\begin{array}{l}\text { Giving animals, } \\
\text { raising or training } \\
\text { animals for matches }\end{array}$ & 1-2 years & $\begin{array}{l}\text { Fine or imprisonment } \\
\text { up to 6 months } \\
\text { months }\end{array}$ & $\begin{array}{l}3 \text { months- } \\
2 \text { years }\end{array}$ \\
\hline $\begin{array}{l}\text { Placing bets on } \\
\text { matches }\end{array}$ & 6 months- 1 year & $\begin{array}{l}\text { Fine or up to two } \\
\text { months }\end{array}$ & $\begin{array}{l}2 \text { months- } \\
2 \text { years }\end{array}$ \\
\hline
\end{tabular}

81 Art. 207/ç, Albanian Criminal Code, op. cit. (fn. 8).

82 Art. 521-1, Penal Code of the Republic of France, op. cit. (fn. 27).

83 Ibid.

84 Art. 325, Nakazatelen kodeks [Criminal Code of the Republic of Bulgaria], Durzhaven vestnik [Official Gazette], no. 27/2009.

85 Art. 544-quinquies, Italian Criminal Code, op. cit. (fn. 35). 


\subsection{Harming and trading protected wild fauna}

The harming and trading of protected wild fauna is prescribed under Article 202 and Article 202/a of the Albanian Criminal Code. The legislator criminalized the killing, destroying, possessing, taking specimens of protected species of wild flora and fauna or their parts or by-products, violating the requirements of the legislation in force for the protection of wild fauna and protected areas or the permits and authorizations issued by the competent authorities, sanctioned by a fine or up to seven years of imprisonment. ${ }^{86}$ The trade in specimens of protected species of wild flora and fauna, parts or by-products thereof, in violation of the requirements of the legislation in force for the protection of wild fauna and protected areas or permits and authorizations issued by the competent authorities is sanctioned by a fine or up to three years of imprisonment. An exception of illegality is if such things happened to a negligible amount of these specimens and has had a negligible impact on the conservation status of the species. ${ }^{87}$

Article 202 of the Albanian Criminal Code reflects Article 181g, paragraph 1 of the Austrian Criminal Code, however Austrian's punishment is more lenient. The Austrian Code sets the punishment with an upper limit of the sentence of imprisonment amounting to two years. The Albanian punishment is imprisonment with the upper limit of the sentence of being seven years. Article 202/a of the Albanian Criminal Code is similar to the provision of the Slovenian Code: "Whoever illegally possesses, seizes, damages, kills, exports, imports or trades in protected wild animal or plant species, protected animals or plants or their parts, or products made therefrom, shall be punished by imprisonment of up to five years". ${ }^{88}$ These articles transposed into national law the Directive 2008/99/ EC of the European Parliament and of the Council of 19 November 2008 on the Protection of the Environment through Criminal Law by Member States. ${ }^{89}$ The Directive emphasizes: "the killing, destruction, possession or taking of specimens of protected wild fauna or flora species, except for cases where the conduct concerns a negligible quantity of such specimens and has a negligible impact on the conservation status of the species", and "trading in specimens of protected wild fauna or flora species or parts or derivatives thereof, except for cases where the conduct concerns a negligible quantity of such specimens and has a negligible impact on the conservation status of the species". ${ }^{90}$

\footnotetext{
86 Art. 202, Albanian Criminal Code, op. cit. (fn. 8).

87 Art. 202/a, Ibid.

88 Art. 344, Slovenian Criminal Code, op. cit. (fn. 36).

89 Eco Crime Directive, op. cit. (fn. 29).

90 Arts 3(f)-3(g), Ibid.
} 
Table 5. Elements of offences concerning harm or trade of wild species and corresponding sentences in Albanian, Austrian, Croatian and Slovenian Criminal Codes.

\begin{tabular}{|l|c|c|c|c|c|}
\hline \multicolumn{1}{|c|}{ PROVISION } & $\begin{array}{c}\text { Albania } \\
\text { proposed }\end{array}$ & $\begin{array}{c}\text { Albania } \\
\text { adopted }\end{array}$ & Austria & Croatia & Slovenia \\
\hline $\begin{array}{l}\text { Killing or keeping in slavery animals } \\
\text { in risk of extinction, with intention } \\
\text { to profit }\end{array}$ & $2-3$ years & $\begin{array}{c}\text { Fine or } \\
\text { up to 3 } \\
\text { years }\end{array}$ & - & $\begin{array}{c}\text { not } \\
\text { exceeding } \\
3 \text { years }\end{array}$ & $\begin{array}{c}\text { up to 5 } \\
\text { years }\end{array}$ \\
\hline $\begin{array}{l}\text { Killing, possessing or destroying the } \\
\text { developing forms or takes from the } \\
\text { nature protected wild fauna species, } \\
\text { contrary to a legal provision or a decision } \\
\text { of an authority, } \\
\text { unless the action concerns only an } \\
\text { insignificant quantity of developing forms } \\
\text { and has only insignificant effects on the } \\
\text { conservation status of the species }\end{array}$ & - & $\begin{array}{l}\text { Fine or } \\
\text { up to 7 } \\
\text { years }\end{array}$ & $\begin{array}{c}\text { yp to 2 } \\
\text { years }\end{array}$ & - & - \\
\hline
\end{tabular}

\subsection{Reported cases and cases sent to trial}

The yearly report from the General Prosecutor's Office stated that there were two reported cases of animal cruelty offences in the year 2019.91 These were still in progress since the Criminal Code entered into force only in late September of 2019. Out of these two reported cases in 2019, only one resulted in indictment which proceeded to trial. The owner of a companion animal was charged by the prosecution with abandonment of an animal; however the court found the defendant not guilty. ${ }^{92}$

In 2020, there were 13 reported cases of animal cruelty: nine concerning abandonment of a companion animal; three concerning maltreatment of an animal and one concerning the killing of an animal. ${ }^{93}$ Only one case out of the nine concerning abandonment of an animal resulted in a final court decision that found two defendants guilty of this offence. ${ }^{94}$ The remaining reported cases did not proceed to trial..$^{95}$

91 General Prosecutors Office, Annual Report on Criminality in 2019, 28 March 2020, http://www.pp.gov.al/web/kuvendit_raporti_vjetor_2019_28_3_2020_pp_perf_ 1864.pdf (15 November 2020).

92 Ibid. p. 68.

93 General Prosecutors Office, Annual Report on Criminality in 2020, 30 May 2021, https://www.parlament.al/Files/Kerkese/20210518105256Raporti_Vjetor_2020_ Kuvendit_Kriminaliteti.pdf (15 June 2021) p. 277.

94 See chart at p. 277, Ibid.

95 Ibid. 


\section{FINAL REMARIS}

The modern animal rights movement in the 1970s asserted the concept of animal cruelty, calling upon the words of Jeremy Bentham when he wrote of animals, "The question is not, Can they reason?, nor, Can they talk? but, Can they suffer?" ${ }^{96}$ Since then, the English legislature has adopted legal requirements for humane treatment of animals, demanding from persons involved in the movement, restraint, stunning, slaughter or killing of animals to guarantee that no avoidable excitement, pain or suffering is sustained by the animal. ${ }^{97}$ In 2017 , the German legislature has acknowledged that "the unborn animal shall be protected from suffering and pain". ${ }^{8}$ At the European Union level, especially over the last few decades, considerable legislative achievements have happened to promote animal welfare and improve the quality of animals' lives. ${ }^{99}$

Vast academic research confirms a direct correlation between acts of animal cruelty and future criminal activity of offenders; thus, authorities see the need to criminalize this behavior ${ }^{100}$ while ensuring proportional sentencing ${ }^{101}$.

96 Bentham, J., An Introduction to the Principles of Morals and Legislation, ed. by J. H. Burns and H. L. A. Hart, Oxford University Press, 1970, p. 283. See also Singer, P., The Animal Liberation Movement, revised in 2015, Penguin Random House, 1970; Singer, P., In defense of animals, Blackwell Publishing, 1985.

97 Art. 4, para. 1, The Welfare of Animals (Slaughter or Killing) Regulations 1995, No. 731, https://www.legislation.gov.uk/uksi/1995/731/made (30 December 2021).

98 Gesetz zur Änderung futtermittelrechtlicher und tierschutzrechtlicher Vorschriften, G. v. 30.06.2017 [Law to change feed law and animal welfare regulations], BGBl [Federal Law Gazette] I S. 2147 (Nr. 44). See, Getoš Kalac, A.-M., Violence in the Balkans, Springer, 2021, p. 6.

99 European Court of Auditors, Animal Welfare in the EU: closing gap between ambitious goals and practical implementation, 2018, https://www.eca.europa.eu/Lists/ECADocuments/SR18_31/SR_ANIMAL_WELFARE_EN.pdf (29 December 2021), p. 8.

100 McPhedran, S., A review of the evidence for associations between empathy, violence, and animal cruelty, Aggression and Violent Behavior, vol. 14, no. 1, 2009, pp. 1-4; Coston, C. T. M.; Protz, B. M., Kill your dog, beat your wife, screw your neighbor's kids, rob a bank? A cursory look at an individual's vat of social chaos resulting from deviance, Free Inquiry in Creative Sociology, vol. 25, no. 1, 1998, pp. 153-158; Arluke, A.; Levin, J., The relationship of animal abuse to violence and other forms of antisocial behavior, Journal of Interpersonal Violence, vol. 14, no. 1, 1999, pp. 963-75; Nelson, S. L., The connection between animal abuse and family violence: A selected annotated bibliography, Animal Law Review, vol. 17, no. 2, 2011, pp. 377-386; Hoffer, T. A; Hargreaves-Cormany, H.; Muirhead, Y.; Meloy, J. R., Violence in Animal Cruelty Offenders, Springer, 2018.

101 Bagaric, M.; Kotzmann, J.; Worf, G., Rational approach to sentencing offenders for animal cruelty: normative and scientific analysis underpinning proportionate penalties for animal 
While comprehensive animal cruelty controls still require significant advancements, the Albanian legislature has taken an important step in curbing such cruelty by amending the Criminal Code with animal cruelty offences. Creating written laws marks a significant progress especially given the previous inadequacies of special laws that foresaw only administrative condemnation. In this context, the amendments to the Criminal Code can be hailed as a "defining moment" for animal law in Albania. For the first time in the country's history, electors used their Constitutional right of initiative to propose legislation. Especially because of this context, the issue of animal suffering in the law gained increased visibility. There was undeniable proof of the strong public concern for animal welfare. At the same time, there was proof of a social mindset that problems are solved through criminal law.

The centerpiece of these amendments is the protection of wild fauna by criminalizing behavior that causes it to be killed, destroyed, possessed, traded (as a whole or parts of it). This indicates that cruelty towards wild and protected species is incrementally present in Albania, necessitating systematic institutional action and accountability. Furthermore, amendments, especially with regards to these protected animals, bring Albanian legislation closer to EU acquis by transposing the Directive on ECO Crime into national law.

The initial proposal envisaged harsh sentences for animal cruelty based on a recognition of animal abuse as serious. The adopted amendments can be treated as progress, as they provide for shorter prison sentences justified by an interest in proportionality.

A major challenge that remains is the policing and prosecution of these offences. Whilst pressure from animal organizations may incite individual prosecutions for particular cases of abuse, the main achievement of this reform would be an increased number of proactive efforts to pursue prosecutions by the State Prosecutors in the country. Increased investigations would definitely draw attention to animal abuse and confirm that these amendments are impactful.

In addition to the criminal law perspective, efforts need to be taken to promote animal welfare. A good starting point would be to review animal law in order to situate it in line with EU acquis. The main legal act concerning animals, the Law on Veterinary Service, is in need of revision to transpose the relevant EU

cruelty offenders, South Carolina Law Review, vol. 71, no. 4, 2019, pp. 385-448. See also, Lamparello, A.; Boyd, M., Vulnerable Victims: Increasing Animal Cruelty Sentences to Reflect Society's Understanding of the Value of Animal Lives, Connecticut Law Review, vol. 45, no. 4, 2013, pp. 31-40. 
Directives. ${ }^{102}$ The Albanian legislature has yet to transpose Directive 2010/63/ EU (2010), which pertains to the protection of animals used for scientific purposes: minimum standards for housing and care, as well as systematic project evaluation requiring, inter alia, an assessment of pain, suffering, distress, and lasting harm caused to the animals. The Directive also requires regular risk-based inspections and improves transparency through measures such as publication of non-technical project summaries and retrospective assessment. ${ }^{103}$ The Albanian government also needs to transpose Directive and Regulation laying down rules for the welfare of chickens kept for meat production, including marking and tracing of specific animals and addressing transmissible diseases. ${ }^{104}$

This work aimed to clarify this development and provide a comparative account of the criminalization of animal cruelty in Albania, the nine jurisdictions and the EU acquis. The conducted interviews clarified Albanian society's perception of animal cruelty. The anti-cruelty provisions in the Criminal Code display the moral progress of this society and Albanian citizen's intentions to protect animals.

Additional research is needed to explore the application of these provisions: How many cases of animal cruelty will be reported to the State Police on yearly basis? Will the office of the prosecutor indict a large number of cases? What stance will judges take in punishing animal cruelty? How will this impact the general public in terms of individual or general deterrence?

102 Law on Veterinary Services, op. cit. (fn. 7), p. 1.

103 EU Directive 2010/63/EU (2010), revising Directive 86/609/EEC on the protection of animals used for scientific purposes, 22 September 2010. https://eur-lex.europa. eu/LexUriServ/LexUriServ.do?uri=OJ:L:2010:276:0033:0079:en:PDF (15 January 2021). Complimentary to the Directive the European Commission, the Law should make reference to the Recommendation 2007/526/EC, which introduces guidelines for the accommodation and care of animals used for experimental and other scientific purposes, and sets down firm rules on requirements for accommodation and care of experimental animals. Recommendation 2007/526/EC, Guidelines for the accommodation and care of animals used for experimental and other scientific purposes (notified under document number C(2007) 2525, 18 June 2007. https://eurlex.europa.eu/LexUriServ/LexUriServ.do?uri=OJ:L:2007:197:0001:0089:EN:PDF (15 January 2021).

104 Council Directive 2007/43/EC of 28 June 2007 laying down minimum rules for the protection of chickens kept for meat production, https:/eur-lex.europa.eu/eli/ dir/2007/43/2019-12-14 (10 September 2021); Regulation (EU) 2016/429 of the European Parliament and of the Council of 9 March 2016 on transmissible animal diseases and amending and repealing certain acts in the area of animal health, https://eur-lex.europa.eu/eli/reg/2016/429/2021-04-21 (15 September 2021). 


\section{BIBLIOGRAPHY}

\section{Academic Literature}

Anderson, J. L., The Origins and Efficacy of Private Enforcement of Animal Cruelty Law in Britain, Drake Journal of Agricultural Law, vol. 17, no. 2, 2012, pp. 263-310.

Arluke, A.; Levin, J., The relationship of animal abuse to violence and other forms of antisocial behavior, Journal of Interpersonal Violence, vol. 14, no. 1, 1999, pp. 963-975. DOI: 10.1177/088626099014009004.

Bagaric, M.; Kotzmann, J.; Worf, G., Rational approach to sentencing offenders for animal cruelty: normative and scientific analysis underpinning proportionate penalties for animal cruelty offenders, South Carolina Law Review, vol. 71, no. 4, 2019, pp. 385-448.

Bentham, J., An Introduction to the Principles of Morals and Legislation, in J. H. Burns and H. L. A. Hart (eds.), Oxford University Press, 1970.

Burchfield, K., The Sociology of Animal Crime: An Examination of Incidents and Arrests in Chicago, Deviant Behavior, vol. 37, no. 4, 2016, pp. 368-384. DOI: 10.1080/01639625.2015.1026769.

Cani, E., Legal Regulation of Administrative Misdemeanours: European Principles and the Case of Albania, International Journal of Innovation Sciences and Research, vol. 4, no, 3, 2015, pp. 105-112.

Çomo, J., E Drejta Administrative e RSH [Administrative Law in the Republic of Albania], (7th ed.), 2016.

Coston, C. T. M.; Protz, B. M., Kill your dog, beat your wife, screw your neighbor's kids, rob a bank? A cursory look at an individual's vat of social chaos resulting from deviance, Free Inquiry in Creative Sociology, vol. 25, no. 1, 1998, pp. 153-158.

Favre, D.; Tsang, V., The development of the anti-cruelty laws during the 1800's, Detroit College of Law Review, vol. 1, no. 1, 1993, pp. 1-35.

Flyn, C. P., Battered Women and Their Animal Companions: Symbolic Interaction Between Human and Nonhuman Animals, Society and Animals, vol. 8, no. I, 2000, pp. 99-105. DOI: 10.1163/156853000511032.

Flyn, C. P., Understanding animal abuse: A sociological analysis, Lantern Books, 2012.

Getoš Kalac, A.-M., Violence in the Balkans, Springer, 2021.

Hoffer, T. A., Hargreaves-Cormany, H.; Muirhead, Y.; Meloy, J. R., Violence in Animal Cruelty Offenders, Springer, 2018.

Lamparello, A.; Boyd, M., Vulnerable Victims: Increasing Animal Cruelty Sentences to Reflect Society's Understanding of the Value of Animal Lives, Connecticut Law Review, vol. 45, no. 4, 2013, pp. 31-40. 
Luke, C.; Arluke, A., Physical cruelty toward animals in Massachusetts, 1975-1996, Society \& Animals, vol. 5, 1997, pp. 195-204. DOI: 156853097X00123.

McPhedran, S., A review of the evidence for associations between empathy, violence, and animal cruelty, Aggression and Violent Behavior, vol. 14, no. 1, 2009, pp. 1-4.

Mogbo, T. C.; Oduah, F. N.; Okeke, J.; Ufele, A. N.; Nwankwo, O. D., Animal Cruelty: A Review, Journal of Natural Sciences Research, vol. 3, no. 8, 2013, pp. 94-98.

Nelson, S. L., The connection between animal abuse and family violence: A selected annotated bibliography, Animal Law Review, vol. 17, no. 2, 2011, pp. 377-386.

Piazza, J.; Landy, J. F.; Goodwin, G. P., Cruel nature: Harmfulness as an important, overlooked dimension in judgments of moral standing, Cognition, vol. 131, no. I, 2014, pp. 108-124. DOI: 10.1016/j.cognition.2013.12.013.

Priest, C., Enforcing Sympathy: Animal Cruelty Doctrine after the Civil War, Law \& Social Inquiry, vol. 44, no. 1, 2019, pp. 136-139. DOI: 10.1017/1si.2018.

Schmitthoff, M., The Science of Comparative Law, Cambridge Law Journal, vol. 7, no. 1, 1939, pp. 94-110. DOI: 10.1017/S0008197300127618.

Singer, P., In defense of animals, Blackwell Publishing, 1985.

Singer, P., The Animal Liberation Movement, revised in 2015, Penguin Random House, 1970.

Van Hoecke, M., Methodology of Comparative Legal Research, Law and Method. vol. 1, 2014, pp. 1-35. DOI: 10.5553/REM/.000010.

Wright, J.; Hensley, C., From Animal Cruelty to Serial Murder: Applying the Graduation Hypothesis, International Journal of Offender Therapy and Comparative Criminology, 2003, pp. 71-88. DOI: 10.1177/0306624X02239276.

\section{Legal Acts}

Ligji nr. 8471, datë 22.11.1998 Kushtetuta e Republikës së Shqipërisë [Law nr. 8471 Constitution of the Republic of Albania], Fletorja Zyrtare [Official Gazette], no. 219/1998.

Ligj nr. 10253, datë 11.3.2010 Për gjuetinë [Law on Hunting], Fletorja Zyrtare [Official Gazette], no. 39/2010.

Ligj nr. 10465, datë 29.9.2011 Për shërbimin veterinar në Republikën e Shqipërisë [Law on Veterinary Services], Fletorja Zyrtare [Official Gazette], nr. 143/2011. Ligj nr. 10 006, datë 23.10.2008 Për mbrojtjen e faunës së egër [Law on Protection of Wildlife], Fletorja Zyrtare [Official Gazette], nr. 153/2008. 
Ligji nr. 10 279, datë 20.5.2010 Për Kundërvajtet Administrative [Law on Administrative Misdemeanors], Fletorja Zyrtare [Official Gazette], nr. 120/2010.

Ligj nr. 44/2019, date 18.7.2019 Për disa shtesa dhe ndryshime në Ligjin nr. 7895, date 27.1.1995 “Kodi Penal i Republikës së Shqipërisë [Law amending the Criminal Code of the Republic of Albania], Fletorja Zyrtare [Official Gazette], nr. 131/2019.

Nismë e qytetarëve për miratimin e disa dispozitave në Kodin Penal kundër dhunës ndaj $k a f s h e ̈ v e$ [Citizens proposal to ammend the Criminal Code with provisions on violence against animals] Proposal submitted to the Albanian Parliament, https://www.parlament.al/Files/ProjektLigje/nisma-e-qytetareve.pdf (15 February 2021).

Code pénal de la République française [Penal Code of the Republic of France], Official Gazzete [Journal officiel], no. 286/2009.

Codice Penale [Italian Criminal Code], Gazzetta Ufficiale [Official Gazette], nr. 36/2019.

Strafgesetzbuch - StGB [Austrian Criminal Code], Amstblatt [Official Gazette], nr. 60/1974 (last amended 5.2.2020).

Kazneni Zakon [Croatian Criminal Code], Narodne Novine [Official Gazette], no. $144 / 2012$.

Kazenski Zakonik [Slovenian Criminal Code], Uradni List [Official Gazette], no. 55/2002.

Nakazatelen kodeks [Criminal Code of the Republic of Bulgaria], Durzhaven vestnik [Official Gazette], no. 27/2009.

Wetboek van Strafrecht [Criminal Code of Kingdom of Netherlands], Staatsblad [Official Gazette], accessed the official translated version at: http://www. ejtn.eu/PageFiles/6533/2014\%20seminars/Omsenie/WetboekvanStrafrecht_ENG_PV.pdf (13 February 2021).

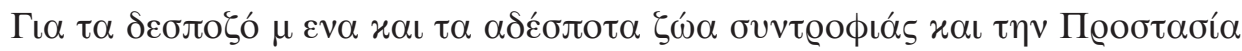

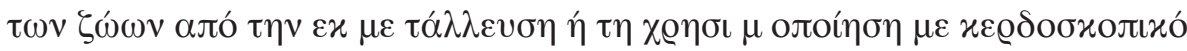
бxолó [The Law on Domestic and Stray Pets and Animal Protection in

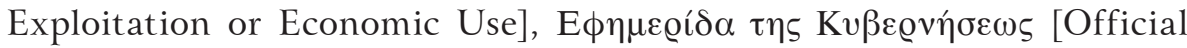
Gazette], no. 4039/2012, accessed in English at https:/www.digihome.eu/ law-number-40392012-government-gazette-a-15-for-home-pets-and-straypets-and-to-protect-animals-from-exploitation-or-use-for-profit/ (23 December 2021).

Wet Dieren [Animal Protection Act of the Kingdom of Netherlands], Staatsblad [Official Gazzette], no.05/11. 
Zakon o zaštiti životinja [Animal Protection Act of the Republic of Croatia], Narodne novine [Official Gazette], no. 102/2017. Consulted in English language at: http://www.mvep.hr/files/file/dokumenti/prevodenje/zakoni/25-Zakon-o-za\%C5\%Altiti-\%C5\%BEivotinja--NN-102-17-ENG.pdf (13 February 2020).

\section{European Acts and Other Reports}

Agerholm, H. "Rundown prison": Three lions and one bear among animals rescued from "shocking" Albanian zoo, The Independent, 29 October 2018, https://www. independent.co.uk/news/world/europe/albania-zoo-animal-rescue-malnourished-treatment-cruelty-a8607451.html (30 December 2021).

Council Directive 2007/43/EC of 28 June 2007 laying down minimum rules for the protection of chickens kept for meat production, https://eur-lex.europa. eu/eli/dir/2007/43/2019-12-14 (10 September 2021).

Criminal Justice of the Strategy of the Judicial Reform in Albania, 24 July 2015, https://rm.coe.int/strategy-on-justice-system-reform-24-07-2015en/16809eb53b (10 September 2020).

Decree of 16 May 1997, concerning rules on the killing of animals, having regard to Directive No 93/1919/EC of the Council of European Union. http://www. fao.org/faolex/results/details/en/c/LEX-FAOC018522 (15 February 2021).

Dungler, H., 'Four Paws Foundation for Animal Welfare Annual Report', VIER PFOTEN International, 2016, https://media.4-paws.org/f/b/d/2/fbd22b819dle83fcfbaec2f9254c0dfa3f6cdd03/180221_GB2016_INT.pdf. (21 June 2021).

Emiri, G. Illegal hunting set new records during the pandemic, Reporter.al, 2021, https:// www.reporter.al/gjuetia-e-paligjshme-shenoi-rekorde-te-reja-gjate-pandemise/ (30 December 2021).

EU Charter of the Charter of the Fundamental Rights of the European Union, https://eur-lex.europa.eu/legal-content/EN/TXT/?uri=CELEX:12012P/TXT (10 December 2020)

EU Directive Directive 2008/99/EC of the European Parliament and of the Council of 19 November 2008 on the Protection of the Environment through Criminal Law (ECO Crime Directive), https://eur-lex.europa.eu/legal-content/ EN/TXT/?uri=CELEX\%3A32008L0099 (10 February 2020).

EU Directive 2010/63/EU (2010), revising Directive 86/609/EEC on the protection of animals used for scientific purposes, 22 September 2010, https:// eur-lex.europa.eu/LexUriServ/LexUriServ.do?uri=OJ:L:2010:276:0033:0079 :en:PDF (15 January 2021). 
EU Regulation 2016/429 of the European Parliament and of the Council of 9 March 2016 on transmissible animal diseases and amending and repealing certain acts in the area of animal health, https:/eur-lex.europa.eu/eli/ reg/2016/429/2021-04-21 (15 September 2021).

European Commission (2020), Albania 2020 Report, SWD (2020) 354, 6.10.2020, https://ec.europa.eu/neighbourhood-enlargement/sites/default/files/albania_report_2020.pdf (15 February 2021).

European Convention of Human Rights, https://www.echr.coe.int/documents/ convention_eng.pdf (10 December 2020).

European Court of Auditors, Animal Welfare in the EU: closing gap between ambitious goals and practical implementation, 2018, https://www.eca.europa.eu/Lists/ ECADocuments/SR18_31/SR_ANIMAL_WELFARE_EN.pdf (29 December 2021).

FOUR PAWS, Bears in Albania: The cruel keeping of bears in captivity nearly set to end, 2021, https://saddestbears.four-paws.org/southeast-europe-campaign/ bears-in-albania (7 October 2021).

FOUR PAWS, Illegal wildlife trade in Albania is out of control, 2020, https://saddestbears.four-paws.org/press-release/illegal-wildlife-trade-in-albania-is-out-ofcontrol (29 December 2021).

General Prosecutors Office, Annual Report on Criminality in 2019, 28 March 2020, https://www.pp.gov.al/web/kuvendit_raporti_vjetor_2019_28_3_2020_ pp_perf_1864.pdf (15 November 2020).

General Prosecutors Office, Annual Report on Criminality in 2020, 30 May 2021, https://www.parlament.al/Files/Kerkese/20210518105256Raporti_Vjetor_2020_Kuvendit_Kriminaliteti.pdf. (15 June 2021).

Mejdini, F., Albania seeks to raise funds for bear shelter following the ill-treatment scandal, Reporter.al, 2016, https://balkaninsight.com/2016/09/01/albania-struggles-to-move-in-sanctuary-caged-bears-08-31-2016/ (24 June 2020).

Mejdini, F., Albania's caged bears enjoy freer life in Kosovo, Reporter.al, 2016, https:// balkaninsight.com/2016/10/24/kosovo-gives-albania-lessons-over-bear-sanctuary-10-21-2016/ (24 June 2020).

Recommendation 2007/526/EC, Guidelines for the accommodation and care of animals used for experimental and other scientific purposes (notified under document number C(2007) 2525, 18 June 2007, https://eur-lex.europa. eu/LexUriServ/LexUriServ.do?uri=OJ:L:2007:197:0001:0089:EN:PDF (15 January 2021).

Wright, S., RESCUED: Lonely bear which became depressed and bit itself after being kept in a tiny cage by an Albanian restaurant will be moved to an animal sanctuary, 
Daily Mail, https://www.dailymail.co.uk/news/article-3703309/Lonely-bear-depressed-bit-kept-tiny-cage-Albania-moved-animal-sanctuary-html (22 July 2020).

Wright, S., Shocking new pictures reveal the sickening cruelty suffered by brown bears in Albania, Daily Mail, 2016, https://www.dailymail.co.uk/news/article-3753130/ Force-fed-beer-paraded-streets-chains-locked-tiny-cages-Shocking-new-pictures-reveal-sickening-cruelty-suffered-brown-bears-Albania.html (22 August 2020). 
Sažetak

\section{Nita Shala* \\ Avni Puka** \\ Gianluigi Pratola***}

\section{KRIMINALIZACIJA OKRUTNOG PONAŠANJA PREMA ŽIVOTINJAMA U KONTEKSTU: ALBANSKA PERSPEKTIVA}

Albansko je zakonodavstvo sporo pristupilo sveobuhvatnom uređenju i kaznenom sankcioniranju okrutnosti prema životinjama. Tijekom drugog desetljeća izgradnje demokratskog pravnog sustava, prihvaćeno je zakonodavstvo prvotno odredilo samo prekršajne kazne za ograničen broj djela okrutnosti prema životinjama, počinjenih komisivno ili omisivno. Međutim, peticija 37.257 glasača iz studenog 2017. obvezala je Odbor za zakonodavstvo Parlamenta Albanije da se raspravi i o kriminalizaciji takvih djela. Dvije godine kasnije, 18. srpnja 2019., usvojene su dopune albanskog Kaznenog zakona kojima je dodano 6 članaka kojima je predviđena kaznena sankcija za djela okrutnosti prema životinjama. Pitanje koje se postavlja u radu jest kako su društveni kontekst i drugi faktori oblikovali pravo kojim su regulirana ova kaznena djela. Cilj autora je odgovoriti na to pitanje funkcionalnom metodom te pristupom koji se temelji na kontekstualnoj analizi rješenja problema, poduzimajući dubinsku pravnu procjenu albanskog zakonodavstva te poredbenih pravnih rješenja. Rad se u velikoj mjeri temelji na zapisnicima osam sastanaka Odbora za zakonodavstvo te razgovorima sa 19 članova Parlamenta, službenicima u odgovornim ustanovama te predstavnicima civilnog društva, kako bi se rasvijetlilo kako su napori društva oblikovali proces $i$ krajnji rezultat kriminalizacije okrutnosti prema životinjama u Albaniji. Rasprava se nastavlja s poredbenopravnom analizom predloženih rješenja $i$ usvojene regulacije u Kaznenom zakonu u odnosu prema zakonodavstvima izabranih zemalja Europske unije i EU acquisem. Iznose se sumnje i zabrinutost je li kriminalizacija okrutnosti prema životinjama odgovarajući način kako bi se smanjio broj takvih postupanja.

Ključne riječi: okrutnost prema životinjama, Kazneni zakon, Albanija, poredbenopravna analiza

* Dr. sc. Nita Shala, MSc (Oxon), asistentica Pravnog fakulteta Sveučilišta u Prištini,

Rr. “Agim Ramadani”, 10000 Priština, Kosovo; nita.shala@uni-pr.edu;

ORCID ID: orcid.org/0000-0003-1518-0756

** Dr. sc. Avni Puka, docent Pravnog fakulteta Sveučilišta u Prištini, Rr. "Agim Ramadani”, 10000 Priština, Kosovo; avni.puka@uni-pr.edu (Corresponding Author);

ORCID ID: orcid.org/0000-0002-7562-5078

*** Dr. Gianluigi Pratola, tužitelj, zamjenik državnog odvjetnika pri Kasacijskom sudu Italije, međunarodni ekspert za EURALIUS Project u Albaniji, Ministry of Justice, Zogu I Bulevard, 1000 Tirana, Albanija; pratola@euralius.eu;

ORCID ID: orcid.org/0000-0003-1854-6055 